\title{
Supervisors' Perceptions of the Performance of Cooperative Education Employees Working in Federal Agencies
}

\author{
James W. Douglas, The University of Oklahoma \\ Gene A. Brewer, The University of Georgia
}

\begin{abstract}
Through cooperatwe education programs, many public agencies employ college students part-time or intermittently and groom them for future full-tme employment. The combination of winnowing and nurturng that occurs in these programs is believed to produce higher performing employees. Thus study tests this hypothess by comparing Federal supervisors' perceptions of the performance of co-op employees wuth those recruted from other sources. Data come from the 1992 Mert Prmoples Survey, U.S. Mertt Systems Protection Board. The results indicate that co-op employees perform at high levels, but they do not outperform other employees as a whole. Next, we compare the performance ratungs of Federal workers from seven other recrutment sources to see if any source is superior. Some interesting findings emerge. Of course, performance ratings are an incomplete indicator of an employee's value to the organization. These ratings merely reflect superwisors' perceptions, and whle high performance is important, agencies may wish to promote other goals in their recruatment and retention efforts such as workforce diversity.
\end{abstract}

$\mathrm{T}_{\mathrm{i}, \mathrm{sen}}$ he recruitment and retention of quality employees are major concerns at all levels of government. Low pay and the public's low regard for government employment have made it difficult for the public sector to attract and retain personnel (Volcker, 1990; but see Crewson, 1995). Scarce resources force government personnel officers to seek out and hire higher quality employees in order to maximize productivity and minimize costly turnover rates (Lane \& Wolf, 1990). Finding good workers is also important because civil service protections make it difficult for public managers to deal with poor performers (Hays \& Reeves, 1984; U.S. Merit Systems Protection Board, 1998).

Unfortunately for public personnel officers, competing with the private sector for quality employees is not an easy task (U.S. General Accounting Office, 1994a, 1994b).
Current conditions in the labor market make this task even more difficult. Knowledgeable and skilled workers may not be available in large numbers, and they may not be inclined to work for government (Blank, 1985; U.S. General Accounting Office, 1994b). ${ }^{1}$ Currently, aging baby boomers make up a large portion of government employment rolls. ${ }^{2}$ Replacing these employees is becoming more difficult because fewer young workers are entering the job market (Lane \& Wolf, 1990). In addition, the demand for workforce diversity is increasing. This demand is particularly difficult to satisfy in an era of personnel reductions and declining support for affirmative action (Crewson \& Guyot, 1997).

To bolster their recruitment efforts, many government agencies participate in cooperative education programs in conjunction with colleges and universities through- 
out the country. This article explores cooperative education programs in the Federal government. ${ }^{3}$ After reviewing the literature, we test the hypothesis that Federal workers recruited through these programs perform at higher levels than other workers. We then branch out and compare the performance ratings of Federal workers from seven other recruitment sources to see if any source is superior. The article ends by discussing the findings and identifying several avenues for future research.

\section{LITERATURE REVIEW}

Cooperative education programs integrate college study with professional work. Generally, college students participating in these programs alternate between periods of fulltime study and full-time work. ${ }^{4}$ Participation in such programs gives students valuable work experience and enables them to see the connection between theory and practice. However, the time devoted to work usually forces students to spend an extra year in college (Ross \& Marriner, 1985; Stern, 1997).

Cooperative education was developed by Herman Schneider, who began the first such program in the University of Cincinnati College of Engineering in 1906 (Heinemann, Wilson, Heller \& Craft, 1982; Grubb \& Villeneuve, 1995). Since then, more than 1,000 colleges and universities have begun cooperative education programs in a variety of disciplines. A decade ago, Tyler (1987) reported that 80,000 employers and 200,000 students were participating in such programs. These numbers have increased sharply in the 1990s (Bailey, Hughes $\&$ Barr, 1998; World Association for Cooperative Education, 1998).

Many co-op students are employed by government agencies. One study reported that as many as 23 percent of cooperative education students were employed in the public sector (Rowe, 1987). Another study reported that many co-op employers are "philosophically oriented towards public service," and that public sector and nonprofit firms are the mainstays of the participant pool (Bailey, Hughes, \& Barr, 1998). ${ }^{5}$ The U.S. Federal government is the nation's largest employer, and the largest employer of coop students with almost 14,000 students in 41 agencies (Octameron Associates, 1984; Cooperative Education Association, 1998). Despite these numbers, nothing has been written about the benefits cooperative education programs provide government agencies specifically. Most of the research has focused on the benefits to employers in general, the benefits derived from employees in specific fields such as engineering, the benefits provided by students from certain schools, or the benefits received by particular firms.

Much of the literature speculates about the potential benefits employers receive from participating in cooperative education programs. These benefits include lower recruitment costs, higher recruitment yields, obtaining higher quality employees, improved access to qualified minorities, higher levels of employee job satisfaction, and lower turnover rates (Porter, 1982; Rowe, 1988; Ross \& Marriner, 1985; Bailey, Hughes, \& Barr, 1998; Grubb \& Villeneuve, 1995). Several of these claims have been examined in empirical research.

First, several studies have explored the recruitment benefits offered by cooperative education. Deane, Frankel, and Cohen (1978) surveyed 250 co-op employers and 125 non-co-op employers, and reported that about 74 percent of co-op employers believed that their co-op programs were helpful in evaluating prospective permanent employees. In addition, more than 87 per- 
cent of co-op employers viewed co-op participation as important in finding permanent employees. The larger the firm, the more likely it was to view co-op participation as important. Co-op employers also disclosed that almost 40 percent of their co-op students accepted positions as full-time employees upon graduation. In Cincinnati, Grubb and Villeneuve (1995) reported that between 60 and 90 percent of co-op students were offered full-time jobs upon graduation, depending on economic conditions. In another study, Wilson and Lyons (1961) reported that all thirty companies they surveyed agreed that cooperative education provided a flow of talent into the company, furnished the opportunity to evaluate prospective full-time employees, and reduced recruitment costs. These findings are further supported by Campbell's (1983) study of the co-op program at Hershey Foods Corporation. He found that many company managers viewed the co-op program as important in locating and evaluating potential full-time employees.

Hayes and Travis (as reported in Brown, Franks \& Garrett, 1986) conducted a survey of seventy employers participating in cooperative education programs. They found that interviewees who had recently graduated from college were nine times more likely to be offered jobs if they were co-op students than if they were non-co-ops. The authors also found that co-op employers were twice as likely to have their job offers accepted by co-op students than by other recent college graduates. Finally, they found that the recruiting yield (the number of jobs accepted as a percentage of the number of candidates interviewed) "was thirteen times higher for co-op students ( 40 percent) than for recent college graduates ( 3 percent)" (Hayes \& Travis, 1976, 15). These studies indicate that cooperative education programs can be a valuable tool for recruiting employees.

Job performance is another aspect of cooperative education that has been studied empirically. How do former co-op students perform once they become permanent employees? Hayes (1978) studied the work performance evaluations of seventy private sector employers over a ten-year-period. He found that co-op graduates tended to receive higher performance ratings than nonco-op graduates. Ehrlich (1978) surveyed thirty-four employers who participated in the co-op program at LaGuardia Community College. He found that employers rated LaGuardia co-op graduates at entry level positions higher on twelve performance attributes than non-co-op graduates working at the same positions. Campbell (1983) echoed these findings when he reported that all of the permanent co-op graduates working for Hershey Foods Corporation were performing at above average levels.

Several studies have attempted to measure performance by studying salaries and job promotions. Gillin, Davie, and Beissel (1984) surveyed 297 co-op and non-co-op engineering graduates. They found that coop graduates tended to earn higher salaries and hold higher level positions after one to five years of employment. It is unclear how employees with more years of service would compare, however. Phillips (1978) examined the employment records of the Lockheed-Georgia Company between 1952 and 1973 and found that co-op graduates in engineering tended to be promoted faster and earn larger pay increases than non-coop graduates in engineering. These results held true even after fifteen years of employment. Alwell (1977) conducted a survey of 1973 and 1974 graduates of Marymount College. He too found that co-op graduates tended to earn significantly higher salaries than non-co-op graduates. In contrast 
to these findings, Rowe (1992) surveyed 259 1988 and 1989 graduates of the University of Waterloo and found that co-op graduates tended to earn higher salaries than non-coop graduates who graduated the same year. However, when 1989 co-op graduates were compared with 1988 non-co-op graduates, no significant difference in salaries was discovered. Still, most of these studies indicate that co-op graduates are higher caliber employees than non-co-op graduates.

Only a few studies have examined the relationship between cooperative education programs and turnover rates. The results of these studies are inconclusive. Gillin, Davie, and Beissel's (1984) study found that co-op engineering graduates tended to change jobs less often than non-co-op engineering graduates. In their review of six in-depth case studies of different employer institutions, Neilsen and Porter (1983, p. 18) reported that former co-op graduates "had higher retention rates (less attrition) than regular college graduates." Yet Phillips' (1978) analysis of engineers at the Lockheed-Georgia Company showed no difference in the retention rates of co-op and non-co-op graduates.

Many employers seem to believe that participating in cooperative education programs is beneficial to them. Surveys show that more than 90 percent of employers conducting co-op programs plan to continue using them (Deane, Frankel \& Cohen, 1978; Ehrlich, 1978). According to Grubb and Villeneuve (1995), the only reason ever given by an employer for discontinuing coop participation in Cincinnati was downsizing. Indeed, most of the cooperative education research indicates that coop programs are beneficial. However, this research is limited in several ways that make it unwise to assume that cooperative education programs are beneficial to govern- ment agencies. First, none of the research focuses strictly on the public sector. In fact, much of it deals solely with the private sector. If public sector organizations differ from private sector organizations, the results of these studies may not hold true in public agencies. Second, several studies only examine the effects of co-op programs on specific firms. As a result, generalizing these results to government agencies is problematic. Third, several studies only examine the effects of co-op graduates in certain occupations or from specific schools. Thus, if students in different occupations and from different schools differ from those studied, generalizing would be inappropriate. Finally, some studies only examine co-op graduates during the initial stages of employment. If the effects change with employee tenure, these studies are of limited value. Because of these problems, further research is needed to help Federal agencies evaluate the usefulness of their co-op programs. Carrying out such research is important given the large numbers of co-op students employed at the federal level.

\section{METHODOLOGY AND DATA COLLECTION}

The data for this study come from the 1992 Merit Principles Survey conducted by the U.S. Merit Systems Protection Board (1994). The survey was mailed to a random sample of 20,851 full-time executive branch employees in the Federal government. The response rate was 64 percent.

The survey contained a series of questions asking Federal managers if they had hired any new employees since the beginning of 1990. If so, respondents were asked to report the recruitment source for the hire. Recruitment sources included the following: OPM certificate, certificate based on agency examining, direct-hire authority, outstanding scholar authority, conversion from a co- 
operative education appointment, veterans readjustment appointment, agency merit promotion plan, other, and unknown source. Respondents were also asked to report the grade level of the new employees (GS/GM series), indicate their job classification (engineering, scientific, medical, other professional, or administration), and rate their performance (excellent, very good, adequate, marginal, or poor). Unfortunately, the respondents were not asked to report on several variables of interest such as employee salaries and position levels, turnover rates, diversification, and employee satisfaction. As a result, these are not included in the analysis.

The survey generated 2,093 responses from public managers who had hired employees within the past two years. ${ }^{6}$ The number of hires from each recruitment source were as follows: OPM certificate, 376; certificate based on agency exam, 321; direct-hire authority, 360; outstanding scholar authority, 131; cooperative education conversion, 97; veterans readjustment appointment, 73 ; agency merit promotion plan, 634; other, 66; and unknown source, 35. Readers should note that for some of the recruitment sources, including cooperative education conversions, the number of hires is small. This must be kept in mind when interpreting the results of this study.

Responses to the above questions are used to compare the performance of former cooperative education students with the performance of other types of hires. Based on existing evidence and common assertions in the literature, it is expected that former cooperative education students will perform better than other types of hires. Additionally, we compare the performance ratings of hires from seven other recruitment sources to see if any source is superior.

The data generated from the survey are nominal and ordinal level measures. Therefore, the chi-square and gamma statistics are the most appropriate tests for differences between the recruitment sources.

\section{FINDINGS}

Table 1 provides some descriptive statistics on the grade levels of co-op and non-co-op hires. The table reveals that the vast majority of co-op conversion hires were at the GS 5-7 levels, whereas the non-co-op hires were much more evenly distributed among the different GS-GM levels. This is not surprising since most new hires converted from cooperative education appointments are recent college graduates. We expect that most of them will be hired at entry-level positions.

Table 2 reveals that co-op conversion hires were more likely to be in scientific and engineering vocations than non-co-op hires. Co-op conversion hires were less likely than non-co-op hires to be employed as other types of professionals. A possible explanation for these differences is that government agencies employing scientists and engineers are more familiar with cooperative education programs and therefore more likely to hire cooperative education graduates than other types of agencies. This is a reasonable assumption since cooperative education programs were pioneered in schools of science and engineering. Therefore, agencies employing scientists and engineers are more likely to have longstanding experiences with cooperative education programs and co-op students.

Table 3 shows that performance ratings tend to be very high for co-op conversion hires. Approximately 80.4 percent of coop conversion hires were given scores of excellent or very good, while only 6.2 percent were rated as marginal or poor. However, these high scores are not dramatically 
TABLE 1. Co-op and Non-Co-op Hires by Grade Level

$\begin{array}{lcccc}\text { GS-GM } & \text { Co-op } & \text { Co-op } & \text { Non-Co-op } & \text { Non-Co-op } \\ \text { Grade Level } & \text { Frequency } & \text { PerCent } & \text { Frequency } & \text { PerCent }\end{array}$

\begin{tabular}{lrrrr} 
GS $5-7$ & 77 & 81.9 & 653 & 33.9 \\
GS $9-12$ & 14 & 14.9 & 699 & 36.9 \\
GS/GM 13-15 & 3 & 3.2 & 554 & 29.2 \\
Total & 97 & & 1,896 & \\
\hline
\end{tabular}

TABLE 2. Co-op and Non-Co-op Hires by Job Classification

$\begin{array}{lcccc}\text { Job } & \text { Co-op } & \text { Co-op } & \text { Non-Co-op } & \text { Non-Co-op } \\ \text { Classification } & \text { Frequency } & \text { Percent } & \text { Frequency } & \text { Percent }\end{array}$

\begin{tabular}{lrrrr} 
Scientific & 15 & 15.5 & 202 & 10.7 \\
Engineering & 26 & 26.8 & 272 & 14.4 \\
Medical & 3 & 23.7 & 875 & 46.3 \\
Other Professionals & 23 & 23.7 & 875 & 46.3 \\
Administrative & 21 & 21.6 & 499 & 26.5 \\
Total & 88 & & 1,888 & \\
\hline
\end{tabular}

different from the scores of non-co-ops. The remainder of this section will examine whether co-op conversion hires perform better than non-co-op hires.

Several chi-square tests were run to detect any differences in the performance of co-op conversion hires and non-co-op hires in the early stages of their employment. The results of these tests are reported in Table 4. First, we tested for differences between the performance ratings of all co-op conversion hires and all non-co-op hires. Second, the difference between the performance ratings of co-op conversions and non-co-ops hired at the GS 5-7 levels was tested. This was done because, as expected, most of the coop conversion employees identified in the survey (79.4 percent) were hired at these levels. Focusing part of the analysis on new hires entering government service at entry level positions is therefore appropriate. Given that only 33.9 percent of the nonco-op employees were hired at these levels (see Table 1), and given that employees hired at higher levels are expected to receive higher performance ratings because of greater experience and qualifications, examining all new hires at all levels together could skew the analysis in favor of non-co-op hires. The difference between co-op and non-coop groups was also tested for GS-GM levels 9-15. The rationale here is that experiential learning may be more beneficial to employees holding more responsible or specialized positions.

Next, both co-op conversion hires and non-co-op hires were broken down by job type and tested against each other. Job types 
TABLE 3. Co-op and Non-Co-op Hires by Performance Rating

\begin{tabular}{|c|c|c|c|c|}
\hline Performance & $\mathrm{CO} \cdot \mathrm{OP}$ & $\mathrm{CO} \cdot \mathrm{OP}$ & NON-CO-OP & NON-CO-OP \\
\hline RatiNG & FREQUENCY & Percent & FREQUENCY & Percent \\
\hline Excellent & 39 & 40.2 & 728 & 36.5 \\
\hline Very Good & 39 & 40.2 & 829 & 41.5 \\
\hline Adequate & 13 & 13.4 & 342 & 17.1 \\
\hline Marginal & 5 & 5.2 & 71 & 3.6 \\
\hline Poor & 1 & 1.0 & 261.3 & \\
\hline Total & 97 & & 1,996 & \\
\hline
\end{tabular}

\section{Table 4. Comparative Performance Ratings of Co-op and Non-Co-op Employees, by Grade Level and Job Classification}

Group

All Employees

GS 5.7 Only

GS/GM 9-15 Only

Technical Jobs Only

Nontechnical Jobs Only

GS 5.7 Technical Jobs

GS 5.7 Nontechnical Jobs
CHI-SQUARE

1.854

2.785

4.235

0.633

2.846

2.745

2.428

\section{Significance}

.763

.595

.375

.959

.584

.601

.658 were classified as technical or nontechnical. New hires identified as scientific, engineering, or medical were classified as technical. New hires identified as other professional or administrative were classified as nontechnical. These tests were conducted to see if co-ops with technical backgrounds performed better against non-co-ops than co-ops with nontechnical backgrounds due to the longer experience technical schools have had with cooperative education programs. Finally, both co-op conversion and non-co-op employees hired at the GS 5-7 levels were divided by job type and compared with each another.

Table 4 shows no significant difference in the performance ratings of co-op conversion hires and non-co-op hires along any of the dimensions tested. These null findings strongly suggest that cooperative education programs do not produce better performing employees, at least in the early years of employment, than other forms of recruitment.

Although co-op conversion hires do not perform better than other hires overall, they may outperform those from certain recruitment sources. To explore this issue, coop conversion hires were compared with hires from the other forms of recruitment individually. Table 5 reveals that co-op conversions performed better than employees hired from OPM certificates (significant at the .01 level) and veterans readjustment appointments (significant at the .001 level). The performance ratings of co-op conversion hires were not significantly different from the ratings of the remaining recruitment sources. ${ }^{?}$ 
TABLE 5. Comparative Performance Ratings of Co-op and Non-Co-op Employees, By Recruitment Source

\begin{tabular}{lcc} 
ReCRUITMENT SOURCE & GAMmA & SigNIFICANCE \\
OPM certificate & .301 & .010 \\
Certificate from exam & .024 & .865 \\
Direct-hire authority & .047 & .740 \\
Outstanding scholar & .294 & .099 \\
Veterans readjustment & .510 & .000 \\
Agency merit plan &. .048 & .728 \\
Other &. .042 & .830 \\
\hline
\end{tabular}

\section{TABLE 6. Comparative Performance Ratings of Each Recruitment Source with Other Sources Combined}

\begin{tabular}{lcc} 
RECRUITMENT SOURCE & GAMMA & SigNiFICANCE \\
OPM certificate & .320 & .000 \\
Certificate from exam & .095 & .175 \\
Direct-hire authority & .123 & .068 \\
Outstanding scholar & .362 & .001 \\
Veteran's readjustment & .499 & .000 \\
Agency merit plan & .146 & .008 \\
Other & .100 & .499 \\
\hline
\end{tabular}

The National Performance Review boldly asserts that "to create an effective federal govermment, we must reform virtually the entire personnel system: recruitment, hiring, classification, promotion, pay, and reward systems (Executive Office of the President, 1993, p. 22)." The study recommends decentralizing many aspects of personnel management so that agencies can develop their own personnel systems and public managers can exercise more discretion in hiring and firing. To perform these functions wisely, agencies and public managers need to know more about the relative merits of different recruitment sources. Therefore, the final step of the analysis involves testing the performance ratings of each recruitment source against the remaining sources combined.
The results will show whether any of the recruitment sources tend to yield higher performing employees than the other methods of recruitment as a whole.

Table 6 shows that job hires from four recruitment sources received performance ratings that were significantly different from other methods as a whole. Two sources, OPM certificates and veterans readjustment appointments, yielded employees who performed significantly worse at the .001 level than other hires as a whole, probably due to the fact that these recruitment sources give less hiring discretion to supervisors than many of the other sources. These are the only two sources on which co-op conversions performed significantly better.

Two recruitment sources produced 
hires who received performance ratings significantly better than other methods as a whole. The outstanding scholar authority hires performed better at the .01 level, and the agency merit promotion plan hires performed better at the .05 level.

\section{DISCUSSION AND CONCLUSION}

The analysis shows that graduates of cooperative education programs perform well as a whole, at least as reflected in performance ratings in their first years of employment in a particular position. However, the analysis provides little evidence that co-op conversion hires perform better as a group than hires from other recruitment sources. Coop hires do tend to perform better than OPM certificate and veterans readjustment hires, but these groups also tend to produce lower quality recruits overall. Furthermore, coop conversion hires do not appear to perform better than other recruitment methods as a whole. In contrast, two recruitment sources—outstanding scholar authority and agency merit promotion plan - tend to yield hires who outperform the other recruitment sources as a whole.

The results of this analysis suggest that federal cooperative education programs do not yield employees who outperform hires from other sources. Nevertheless, co-op recruits can be expected to perform at high levels. Employers seeking to recruit the highest performing workers might be better off utilizing programs such as the outstanding scholar authority and agency merit promotion plan programs. In addition, they may want to avoid OPM certificate and veterans readjustment appointment type programs.

This study is far from conclusive. It only examines the performance ratings of employees in the first year or two of their appointments. Co-op conversion hires may perform better than other types of hires over the long term. The results may also vary by agency. Agencies with longstanding cooperative education programs may fare better than agencies with little experience with and perhaps less commitment to their co-op programs. Furthermore, this study does not examine several postulates found in the cooperative education literature. For example, some observers contend that cooperative education graduates are more committed to their employers (i.e., lower turnover) and more satisfied with their jobs than other employees. If these postulates are true, cooperative education programs may provide employers benefits that outweigh slightly higher performance ratings. Future research is needed to answer these questions. In particular, there is a need for case studies in several public agencies. These studies could shed light on the questions raised in this article, and they could provide a fertile seedbed for further inquiry.

Additionally, future research should investigate why outstanding scholar authority and agency merit promotion type programs produce higher performing employees, why OPM certificate and veterans readjustment appointment type programs produce lower performing employees, and what other costs and benefits are associated with these various recruitment sources. At first blush, these findings tend to support the theoretical rationale underlying the $\mathrm{Na}$ tional Performance Review. That is, traditional recruitment sources administered by central personnel bureaus and heavily bound by civil service rules (such as OPM certificate and veterans readjustment) tend to produce lower performing employees. In contrast, recruitment sources that give agencies and public managers more discretion in the hiring process (such as outstanding scholar authority and agency merit promo- 
tion) appear to yield higher performing employees.

In the end, all of these findings are bounded by three limitations. First, since performance ratings merely reflect supervisors' perceptions, they may not be accurate measures of actual performance. Second, an employee's job performance may not fully convey his or her value to the organization. While high performance is important, agencies may wish to promote other goals in their recruitment and retention efforts such as workforce diversity. Regardless, agencies and public managers need to know more about the relative merits of different recruitment sources because these sources remain the principal gateways to government employment. Third, the small sample sizes for some of the recruitment sources, especially cooperative education conversion, increases the probability that sampling error has affected the accuracy of the estimates of the population parameters. As a result, it is possible that larger sample sizes would have produced different results. Each of these limitations need to be considered in future research.

\section{Notes}

'In one study, two-thurds of current federal employees said they either would not or did not know if they would accept a federal job again tf they were making the decision today (U.S. General Accounting Office, 1992). They cited reasons such as little opportunity for promotion and the low prestige of federal employment.

2Between March 1997 and March 1998, the average age of federal workers increased from 44.9 years to 45.3 years, and their average years of service went from 16 to 16.4 years (FEDweek, 1998).

${ }^{3}$ Federal agencies can convert co-op graduates to permanent status, thus bypassing civil service rules that require open competition. In the past, this exception made co-op programs a popular recruiting source, but government downsizing and a rule change by the Office of Management and Budget have sharply curtailed co-op employment in recent years. According to the Office of Personnel Management, the federal government still employed 14, 826 co-op students as of September 1994. After that, the Office of Personnel Management merged cooperative education with other student work programs, so no more recent statistics are obtainable. For those who can find co-op jobs in federal agencies, they are still an inroad to permanent federal employment.

${ }^{4}$ This is known as the alternative model. In contrast, the parallel model splits each day between study and work.

${ }^{5}$ The authors studied twelve cooperative education programs at nine sites and compared a matched sample of 334 participating employers with 334 nonparticipatıng employers.

${ }^{6}$ Unfortunately, respondents only reported new hires and their performance ratıngs within the past two years. It is possible that the performance ratings of the hires would be different in the long term.

'Both chi-square and gamma tests were performed, but to avord redundancy only the gamma results are shown in Table 5 and Table 6 . The chi-square results did not alter the significance of any variable.

\section{References}

Alwell, W. (1977). An evaluation of the Marymount College Cooperative Experiental Education Program. Joumal of Cooperatwe Education, 14 (1), 34-41.

Bauley, T., Hughes, K. \& Barr, T. (1998). Achieving scale and quality in school-to-work internships: Findings from an employer survey (Report MDS-902). Berkeley, California: National Center for Research in Vocational Education.

Blank, R. M. (1985). An analysis of workers' choice between employment in the public and private sectors. Industrual and Labor Relattons Review, 38 (2), 211-224.

Brown, S. J., Franks, P. J. \& Garrett, M. T. (1986). Public service advertising to promote cooperative education. Joumal of Chemical Education, 63 (5), 406-408.

Campbell, L. B. (1983). Cooperative education programs at Hershey Foods Corporation. Joumal of Dary Science, $66,1803-1806$.

Cooperative Education Association (1998, July 14). Interview with anonymous source.

Crewson, P. E. (1995). A comparative analysis of public and private sector entrant quality. American Journal of Political Science, 39 (3), 628-639.

Crewson, P. E. \& Guyot, J. F. (1997). Sartor resartus: A comparative analysis of public and private sector entrant quality re-analyzed. American Joumal of Polatical Science, 41 (3), 1057-1065.

Deane, R. T., Frankel, S. \& Cohen, A. (1978). An analysis of co-op student employer costs and benefits. Joumal of Cooperative Education, 14 (2), 5-53.

Ehrlich, D. J. (1978). Employer assessment of a cooperative education program. Journal of Cooperative Educaton, 14, 75-87.

Executive Office of the President (1993). National Performance Review, from red tape to results: Creattng a govermment that works better and costs less. Washington, DC: U.S. Government Printing Office.

FEDweek (1998, September 2). "Average Age of Feds Creeping Up. Available online: $<$ fedweek@ list.email.pub.com.

Gilln, L. M., Davie, R. S. \& Beissel, K. R. (1984). Evaluating the cateer progress of Australian engincering graduates. Joumal of Cooperatwe Education, $20,53-70$. 
Grubb, W. N. \& Villeneuve, J. C. (1995). Co-operative education in Cincinnatı: Implications for school-towork programs in the U.S. (Report MDS-1045). Berkeley, California: National Center for Research in Vocational Education.

Hayes, R. A. \& Travis, J. H. (1976). Employer experience with cooperative education: Analysis of costs and benefits. Detroit, MI: The Detroit Institute of Technology.

Hayes, R. A.(1978). Employer experience with the work performance of cooperative education employees. Journal of Cooperatwe Education, 14, 93-103.

Hays, S. W.\& Reeves, T. Z. (1984). Personnel management in the public sector. New York: Oxford University Press.

Heinemann, H. N., Wilson, J. W., Heller, B. R. \& Craft, M. (1982). Cooperative education in the United States of America: An historical perspective. Journal of Cooperative Education, 19 (1), 1-14.

Lane, L. M. \& Wolf, J. F. (1990). The human resource crisis in the public sector. Westport, Connecticut: Quorum Books.

Nielsen, R. P. \& Porter, R. C. (1983). Employer benefits and cost effectiveness of cooperative education programs: A review. Joumal of Cooperative Education, 20 (1), 11-24.

Octameron Associates (1984). Eam and leam: Cooperative education opportunities offered By the federal government. Alexandria, Virginia: Octameron Associates.

Phillips, J. J. (1978). An employer evaluation of a cooperative education program. Journal of Cooperative Education, 14 (2), 104-120.

Porter, R. C. (1982). Cooperative education: A social contract for economical renewal. Journal of Cooperative Education, 18 (3), 21-30.

Ross, S. \& Marriner, A. (1985). Cooperative education: Experience-based learning.Nursing Outlook, 33 (4), $177-180$.

Rowe, P. M. (1987). Employer characteristics in a largescale cooperative education program. Journal of Cooperative Education, 24 (1), 7-13.
Rowe, P. M. (1988). The nature of work experience. Canadran Psychologie/Psychologie Canadienne, 29 (1) $109-115$.

Rowe, P. M. (1992). A compatison of cooperative education with two cohorts of regular graduates: Fellow entrants and fellow graduates. Joumal of Cooperative Education 2 (7), 7-15.

Ryder, K. G., \& Wilson, J. W. (1987). Cooperative education in a new era. San Francisco: Jossey-Bass Inc. Publishers.

Stern, D. (1997). The continuing promise of work-based learning. CenterFocus (No. 18). Berkeley, Californı National Center for Research in Vocational Education.

U.S. General Accounting Office (1994a, August 25). The public service: Issues confronting the federal cavilian workforce (GAO/GGD-94-157). Washington, DC.

U.S. General Accounting Office (1994b, September 9) Federal employment: How government jobs are viewed on some college campuses (GAO/GGD-94-181). Washington, DC.

U.S. General Accounting Office (1992, June 18). Federal employment: How federal employees vew the government as a place to work (GAO/GGD-92-91). Washington, DC.

U.S. Merit Systems Protection Board (1998). Federal supervisors and strategic human resources management. Washıngton, DC.

U.S. Merit Systems Protection Board (1994). Workıng for America: An update. Washington, DC.

Volcker, P. A. (1990). Leadership for America: Rebuilding the public service. The report of the National Commission on the Public Service. Lexington, MA Lexington Books.

Wilson, J. W. \& Lyons, E. H. (1961). Work-study college programs: Appratsal and report of the study of cooperative education. New York: Harper \& Brothers Publishers.

World Association for Cooperative Education (1998) About cooperative education. Available online: hetp:/ /www.dac.neu.edu/wace/ 